\title{
Hydrochemical assessment of water quality for irrigation: a case study of the Medjerda River in Tunisia
}

\author{
Selma Etteieb $\cdot$ Semia Cherif $\cdot$ Jamila Tarhouni
}

Received: 12 July 2014/ Accepted: 21 January 2015/Published online: 15 February 2015

(C) The Author(s) 2015. This article is published with open access at Springerlink.com

\begin{abstract}
In order to characterize, classify and evaluate the suitability of Medjerda River water for irrigation, a hydrochemical assessment was conducted. It accounts for $80 \%$ of the total Tunisian surface water. In this paper, hydrographical methods and PHREEQC geochemical program were used to characterize water quality of Medjerda River, whereas its suitability for irrigation was determined in accordance with its electrical conductivity (EC), sodium adsorption ratio (SAR) and sodium concentrations. It was established that the water samples were undersaturated with calcite, dolomite, aragonite, anhydrite, gypsum and halite except in one water sample which is supersaturated with carbonate minerals. The quality assessment of Medjerda River for irrigation purposes showed that some points belonged to the excellent-to-good and good-to-permissible irrigation water categories, while the remaining ones were classified as doubtful to unsuitable for irrigation making the river water use limited to plants with high salt tolerance. Moreover, based on FAO guidelines, almost all water samples may cause immediate salinity to gradual increasing problem but no soil infiltration problems except for two sampling points. However, immediate development or possible increasing of severe toxicity problems may be caused by the continuous use of
\end{abstract}

\section{S. Etteieb $(\bowtie) \cdot$ J. Tarhouni}

Laboratory of Water Science and Technology (LSTE), National Agronomic Institute of Tunisia INAT, 43 Charles Nicolles Street, Menzeh 1, 1082 Tunis, Tunisia

e-mail: selmaetteieb@yahoo.fr

\section{S. Cherif}

Unité de recherche en Chimie des Matériaux et de l'Environnement UR11ES25, ISSBAT, Université de Tunis El Manar, 9, Avenue Dr. Zoheir Safi, 1006 Tunis, Tunisia this water for irrigation due to troublesome concentrations of chloride and sodium.

Keywords Assessment - Analysis - Water quality · Irrigation · River

\section{Introduction}

Water needed for irrigation of cultivated land is being degraded in terms of quantity and quality due to growing demand for the use of water. Moreover, the crop productivity is associated with the quality of soil and the quality of the water available for irrigation. Normally, investigation of irrigation water quality should focus on salt content, sodium concentration, the occurence of nutrients and trace elements, alkalinity, acidity, and hardness of the water. Salinity problem has lead to the loss of fertile soils every year all over the world (Kirda 1997; Nishanthiny et al. 2010; Numaan 2011). Furthermore, water quality deterioration associated with the ever-increasing demand on irrigation water supply leads to the irrigation of farmlands with poorquality water reducing cropland productivity. Water quality for agricultural purposes is determined on the basis of the effect of water on the quality and yield of the crops, as well as the effect on soil characteristics (Ayers and Westcot 1985). The most commonly encountered soil problems used for evaluating water quality are salinity, water infiltration, toxicity and miscellaneous problems (Longe and Ogundipe 2010). However, even water with considerably high salt concentration can be used for irrigation without endangering soil productivity, provided selected irrigation management. The key point is how to maintain existing salt balance in plant root zone (El Ayni et al. 2012). In addition, the increase in salinity of surface waters stems from the 
discharge of high salt concentrations of waste effluents (Chapman 1996; Thilagavathi et al. 2012). In fact, surface water quality is threatened by point source pollution including municipal sewage discharges, industrial wastewater loads and nonpoint source pollution from agriculture (Igbinosa and Okoh 2009; Wua and Chen 2013). Thus, river water quality can be deteriorated by a heavy load of nutrients and contaminants coming from industrial activity discharge of wastewater, domestic sewage and agricultural practices. The aquatic ecosystem can thus be threatened by the presence of potentially toxic, mutagenic, or carcinogenic compounds from sewage discharges inducing various ecological impacts on aquatic life (Igbinosa and Okoh 2009; Nhapi and Tirivarombo 2004; Kanu and Achi 2011).

Since river water is devoted to agricultural uses, its quality should be assessed to safeguard public health and environment (Igbinosa and Okoh 2009). Thus, comprehensive river water quality monitoring is a helpful tool not only to evaluate the suitability of surface water for irrigation, but also to ensure an efficient management of water resources and the protection of aquatic life (Kannel et al. 2007). Although Medjerda River is the most important river in Tunisia and is used for potable water supply and agriculture as well as an important aquatic life place, very few studies dealt with the assessment of its water quality. Most of the available water in the Medjerda catchment is used for agricultural purposes $(84 \%)$. Medjerda River which flows $600 \mathrm{~km}$ through four governorates is a potential area exposed to urban and industrial pollution (Faust et al. 2004). Therefore, the monitoring of environmental parameters is one of the highest priorities in the evaluation of environmental status of water resources and in environmental protection policy (Wua and Chen 2013). Therefore, it is imperative to have reliable information on the characteristics of water quality for assessing its safety for irrigation as well as an effective pollution control and water resource management (Fan et al. 2010).

In this study, we evaluate the water quality of Medjerda River main streamline and its branches at different locations from its upstream to its downstream in Tunisia. This survey allows a hydrochemical characterization and an assessment of the suitability of this surface water for irrigation based on chemical analysis. On a broader scope, this study contributes to the assessment of water resources of the Medjerda River and the development of local information systems to support decision-making in adopting the appropriate measures for the management of water resources.

\section{Study area}

Medjerda basin, running in a west-east direction in northern Tunisia, has its origin in the semi arid Atlas
Mountains of eastern Algeria (Fig. 1). The Medjerda catchment covers approximately $24,000 \mathrm{~km}^{2}$, of which $7,700 \mathrm{~km}^{2}$ are located in Algeria. The average annual temperature in the basin is $17.8^{\circ} \mathrm{C}$ (Faust et al. 2004). Spatial distribution of total precipitations recorded during the sampling day in the rainfall stations located along the river is presented in Fig. 2. Medjerda River originates from the trays of Constantine (Algeria). It passes through northern Tunisia along $600 \mathrm{~km}$ then it opens into an extremely flat alluvial plain before the Gulf of Tunis. The bedrock was characterized upstream by colluvium, calcareous crusts, encrusted pebbles, gypsum crusts, and Triassic rocks. The bedrock colluvium was mainly alluvium, sand, clay and limestone materials. The downstream bedrock was mainly characterized by marl and cretaceous limestone.

Medjerda river basin accounts for about $80 \%$ of the total surface water resources (Bouraoui et al. 2005). It is used for the irrigation of cultivated land which covers an area of 33,173 ha. These irrigated areas consist of nearly a quarter of the total irrigated areas of the country. Moreover, $80 \%$ of the cultivated area is occupied by orchards, cereals, legumes and fodder crops while almost $19 \%$ consist of market gardens. The most common irrigation method is surface irrigation, but its efficiency is low (50-70\%) in comparison to other efficient water systems such as spray (80-85\%) and drip (90-95\%) (Howell 2003; Rogers et al. 1997) which represent $38 \%$ of the public irrigated areas.

\section{Materials and methods}

\section{Chemical analysis}

Surface water samples from Medjerda River (Tunisia) all along its mainstream and branches (Fig. 1) were collected from the mid-stream in May 2013. The sampling date was chosen to correspond to the increase in the irrigation demand at the beginning of the dry season. In this dry period irrigation becomes essential at a time when water quality deteriorates in terms of salinity posing a major risk for irrigated crops and soils (Chabchoub 2011; CIHEAM 1972). These samples were collected in sterile polyethylene terephthalate (PET) bottles at $4{ }^{\circ} \mathrm{C}$ and transported to the laboratory the same day for analysis. During the field survey, some physicochemical parameters were measured in situ such as temperature, $\mathrm{pH}$, electrical conductivity (EC) and dissolved oxygen (DO). The remaining physicochemical parameters were analyzed in the laboratory according to the International Standardization Organization and French standards (NF) as described in Table 1. All experiments were repeated at least three times. 


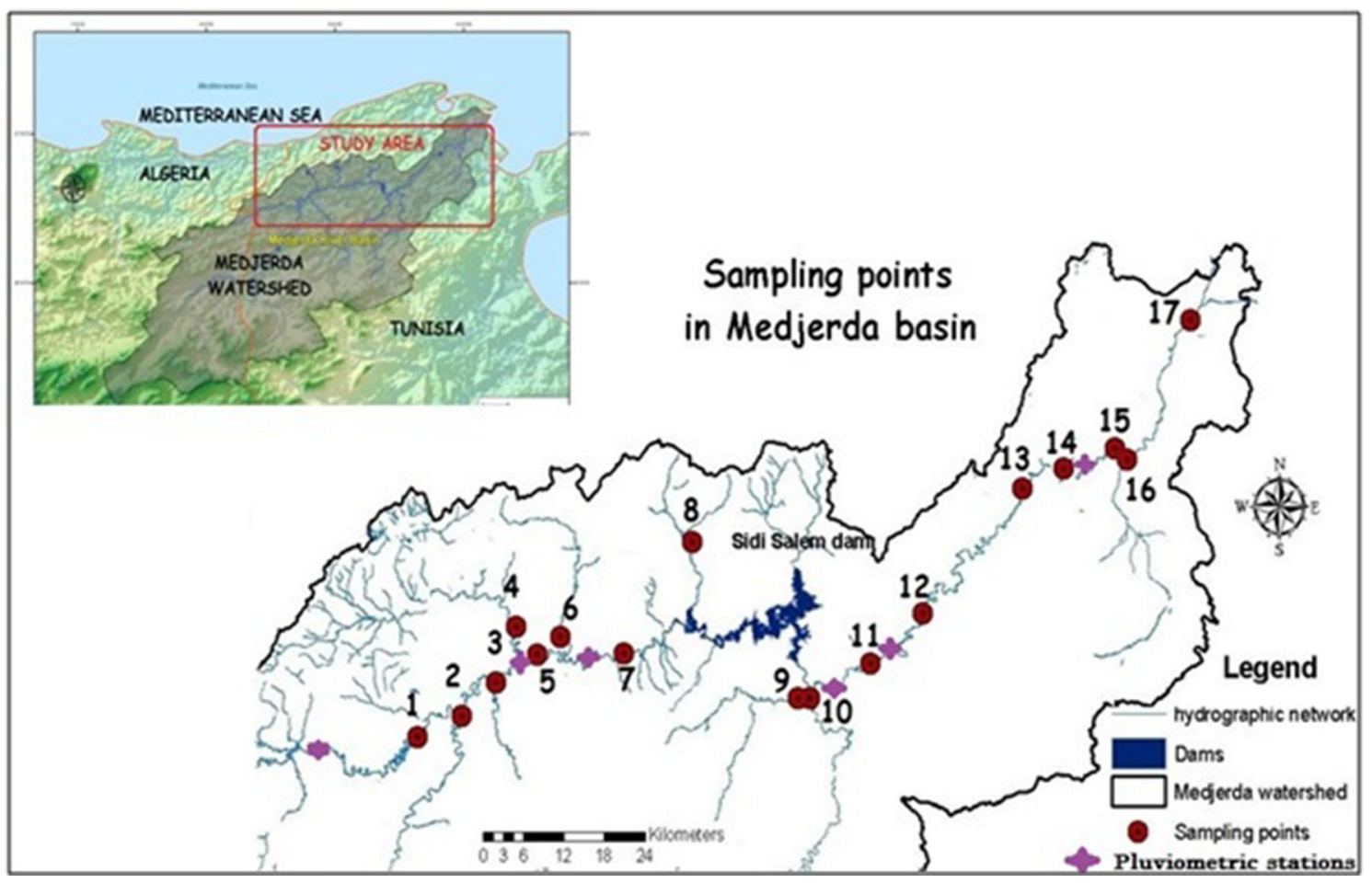

Fig. 1 Medjerda basin in Tunisia and locations of sampling points: 1 Medjerda Jendouba; 2 Mellegue; 3 Tessa; 4 Bouhertma; 5 Medjerda Bousalem; 6 Kassab; 7 Medjerda Beja; 8 Beja; 9 Khalled; 10 Siliana;

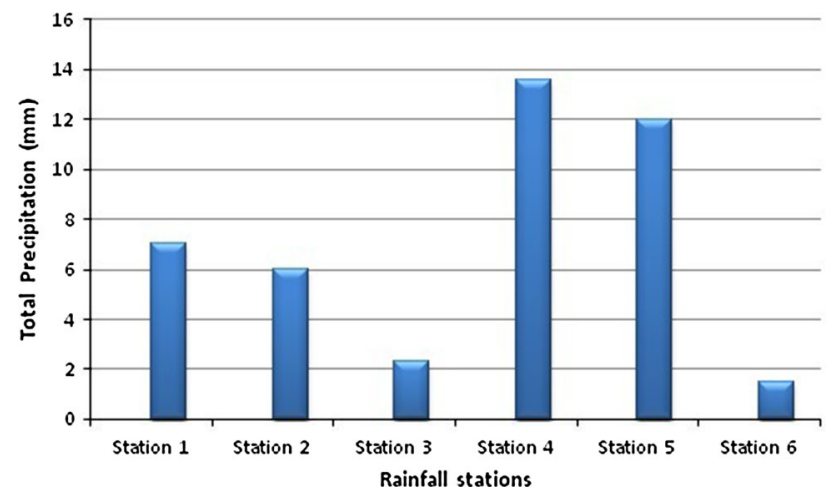

Fig. 2 Spatial distribution of total precipitations registered during the sampling day in the rainfall stations located along Medjerda River

Hydrochemistry of major ions

Geochemical calculations, mainly saturation indexes (SI) were conducted using PHREEQC software v 2.18.3 (Parkhust and Appelo 1999), to evaluate the equilibrium state for each mineral. The SI were used to indicate whether surface water was saturated, undersaturated or oversaturated with respect to minerals (Stumm and Morgan 1996).
11 Medjerda Slouguia; 12 Medjerda Mjez elbab; 13 Laroussia; 14 Battan; 15 Medjerda Jdaida; 16 Chafrou; 17 Medjerda Ariana

The SI of a particular mineral were calculated based on Eq. (1) where IAP is the ion activity product and the solubility constant $K$ is corrected by PHREEQC for ionic strength (Parkhust and Appelo 1999):

$\mathrm{SI}=\log (\mathrm{IAP} / K)$

A neutral saturation index $(\mathrm{SI}=0)$ means the water sample is saturated by minerals and in equilibrium with the solids. A positive or a negative SI means, respectively, that the water sample is oversaturated or undersaturated by minerals.

Irrigation water quality

To assess the excess of sodium in irrigation water, sodium adsorption ratio SAR index was calculated by Eq. (2) using sodium, calcium and magnesium concentrations (meq $\mathrm{L}^{-1}$ ).

$\mathrm{SAR}=\mathrm{Na}^{+}\left(\left(\mathrm{Ca}^{2+}+\mathrm{Mg}^{2+}\right) / 2\right)^{-1 / 2}$

The categorization of hazards was achieved according to FAO regulations (Ayers and Westcot 1985). The percentage of sodium $\left(\% \mathrm{Na}^{+}\right)$was computed with respect to relative proportions of major cations present in 
Table 1 Water quality parameters, analytical methods and detection limits

\begin{tabular}{llll}
\hline Parameters & Method & References & Detection limits \\
\hline Calcium, sodium, magnesium, potassium & Atomic emission ICP & NF EN ISO 11885 & $100 \mu \mathrm{g} \mathrm{L}^{-1}$ \\
Bicarbonates & Titrimetry & NF EN ISO 9963-1 & $8 \mathrm{mg} \mathrm{L}^{-1}$ \\
Chlorides & Ionic chromatography & NF EN ISO 10304-2 & $100 \mu \mathrm{g} \mathrm{L}^{-1}$ \\
Nitrates, sulfates & Ionic chromatography & NF EN ISO 10304-1 & $100 \mu \mathrm{g} \mathrm{L}^{-1}$ \\
\hline
\end{tabular}

water, where the concentration of ion is expressed in meq $\mathrm{L}^{-1}$, using Eq. (3).

$$
\begin{aligned}
\% \mathrm{Na}^{+}= & {\left[\left(\mathrm{Na}^{+}+\mathrm{K}^{+}\right) /\left(\mathrm{Ca}^{2+}+\mathrm{Mg}^{2+}+\mathrm{Na}^{+}+\mathrm{K}^{+}\right)\right] } \\
& \times 100
\end{aligned}
$$

US Salinity Laboratory's diagram (Richards 1954) and Wilcox's diagram (Wilcox 1955) plotting SAR and \% $\mathrm{Na}^{+}$against EC were performed using AquaChem software version 2012.1.123 developed by Schlumberger Water Services. These diagrams were used for the classification of river water for irrigation purposes.

\section{Results and discussion}

\section{Hydrochemistry}

The hydrochemical parameters $\mathrm{pH}, \mathrm{EC}$, cations and anions were characterized by their median, quartiles, maximum and minimum and represented by box plots in Fig. 3. The anion chemistry of the analyzed samples shows that chloride is the dominant ion in most samples. The order of anionic abundance (in $\mathrm{mg} \mathrm{L}^{-1}$ ) is $\mathrm{Cl}^{-}>\mathrm{SO}_{4}^{-}>$ $\mathrm{HCO}_{3}{ }^{-}>\mathrm{NO}_{3}{ }^{-}>\mathrm{CO}_{3}{ }^{-}$. Concerning the cationic chemistry, the order of cationic abundance (in $\mathrm{mg} \mathrm{L}^{-1}$ ) is $\mathrm{Na}^{+}>\mathrm{Ca}^{2+}>\mathrm{Mg}^{2+}>\mathrm{K}^{+}$(Fig. 4).

Water showed a greater variability in the river affluents rather than in the main streamline. The highest values of chloride and sodium were achieved simultaneously for water samples collected in points 3,10 and 16 while their lowest values were noted for water samples collected in points 4 and 6 . Sampling points showed a relatively steady trend for the remaining ion concentrations patterns.

The concentration of sodium composes more than $50.0 \%$ of the total cations in most samples. It reached even $76.4 \%$ in water sample collected in point 8 . For water samples collected in points 4, 6, 11 and 12, the concentrations of calcium are greater than the concentrations of $\mathrm{Na}^{+}$and reach $54.9 \%$. The dominant anion is chloride: its concentration covers more than $50 \%$ of the total anions mass concentrations in most samples. It reaches even

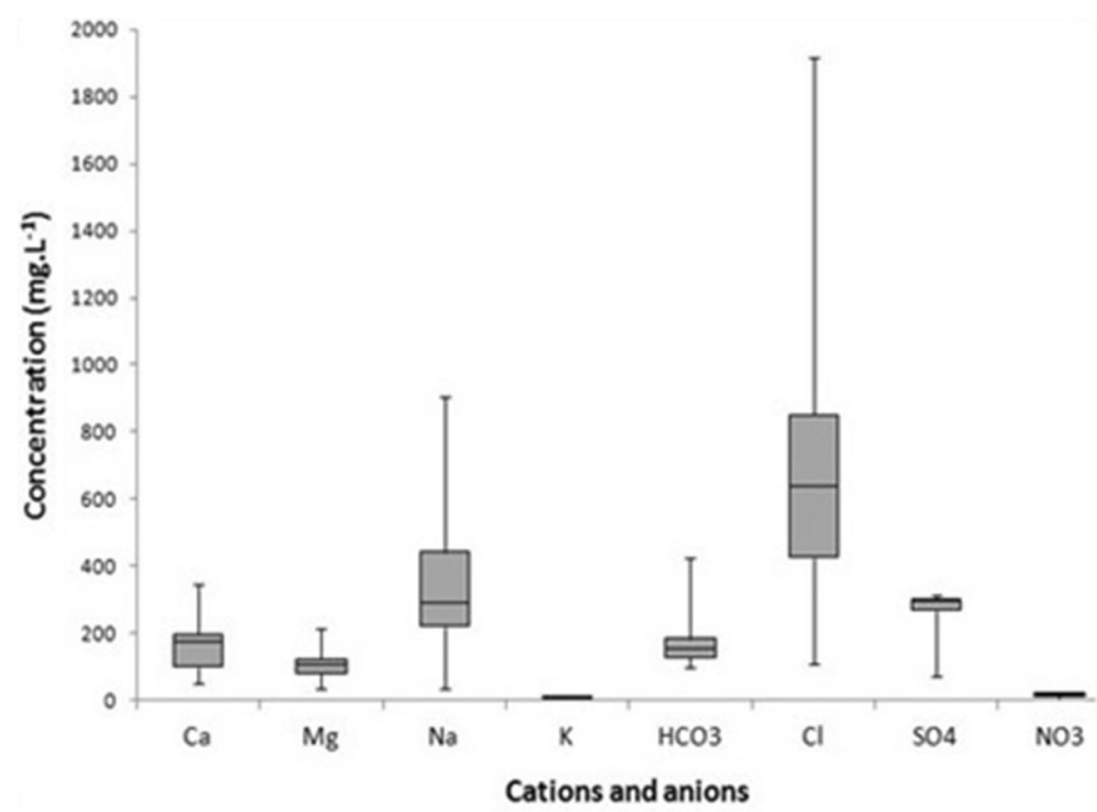

Fig. 3 Hydrochemistry of the river water ( $\mathrm{pH}, \mathrm{EC}$, cations and anions concentrations)
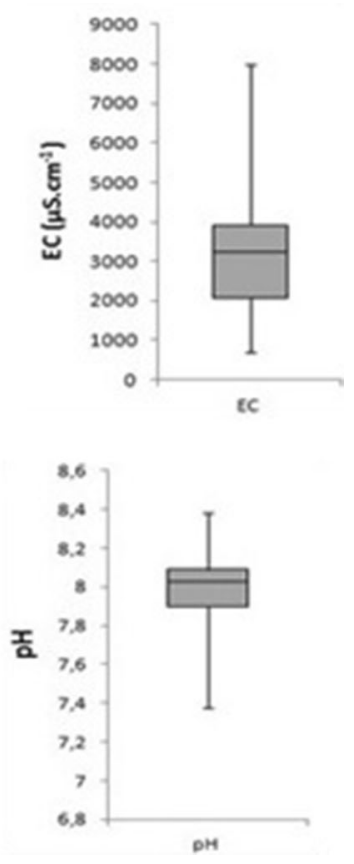

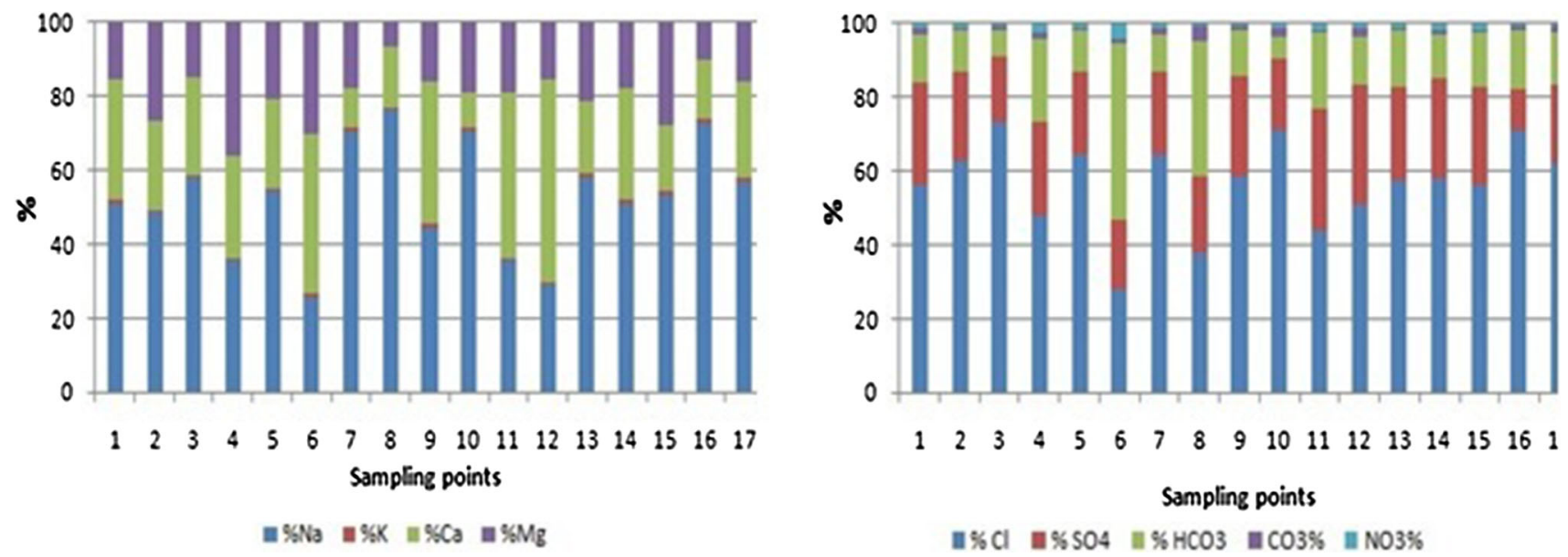

Fig. 4 Changes in cations and anions concentrations along the flow path (\%)

$73.6 \%$ in point 3 . For sample 6, the bicarbonates dominated with $47.6 \%$.

In order to determine the origin of the water hydrochemical facies, the SI of calcite, dolomite, anhydrite, aragonite, halite and gypsum, calculated using PHREEQC geochemical modeling software, were used to determine the chemical equilibrium between these minerals and water. The solubility reactions of calcite (Eq. 4) and dolomite (Eq. 5) and gypsum (Eq. 6) are as follows:

Calcite $\mathrm{CaCO}_{3}+\mathrm{CO}_{2}+\mathrm{H}_{2} \mathrm{O}=\mathrm{Ca}^{2+}+2 \mathrm{HCO}_{3}^{-}$

Dolomite $\mathrm{CaMg}\left(\mathrm{CO}_{3}\right)_{2}+2 \mathrm{CO}_{2+} 2 \mathrm{H}_{2} \mathrm{O}$

$$
=\mathrm{Ca}^{2+}+\mathrm{Mg}^{2+}+4 \mathrm{HCO}_{3}^{-}
$$

Gypsum $\mathrm{CaSO}_{4}+2 \mathrm{H}_{2} \mathrm{O}=\mathrm{Ca}^{2+}+\mathrm{SO}_{4}^{2-}+2 \mathrm{H}_{2} \mathrm{O}$
The SI of calcite, dolomite, anhydrite, aragonite, halite and gypsum are calculated for all the water samples along the flow direction (Fig. 5). The positive and negative SI values represent the thermodynamic potential for precipitation and dissolution, respectively. It can be reported that all the river water samples are undersaturated by minerals except in sampling point 16 which is slightly supersaturated by carbonate minerals (calcite, dolomite and aragonite). Thus, the main chemistry of the river system is controlled by the dissolution of gypsum, halite, anhydrite, aragonite, calcite and dolomite with a precipitation of carbonate minerals in the sampling point 16. The high dissolution rate of carbonate rocks allows waters that are close to saturation with respect to calcite, dolomite and evaporate minerals (gypsum and halite) to remain undersaturated. It leads to a continuing
Fig. 5 Changes in saturation indexes in minerals along the flow path

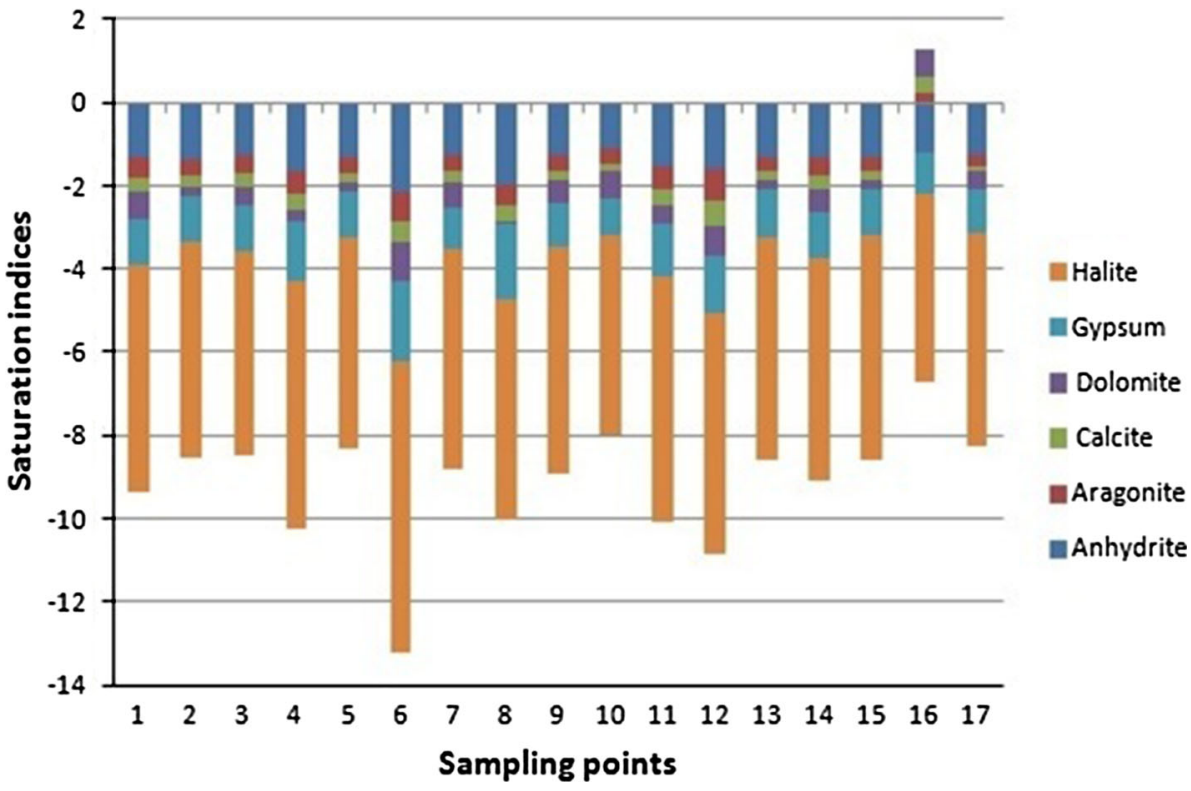


dissolution along the flow paths. The river water has thus the capacity to dissolve gypsum and halite along the flow paths and hence, the concentrations of $\mathrm{Ca}^{2+}, \mathrm{SO}_{4}{ }^{2-}, \mathrm{Na}^{+}$ and $\mathrm{Cl}^{-}$in the river water would increase. This phenomenon has been also discussed by many researchers (Alexakis 2011; Hui et al. 2011; Sappa et al. 2012).

These findings can be explained by the geology of the study area, in particular the variation of the mineralogical composition of the bedrock from upstream to downstream. A similar impact of the bedrock composition to the water quality has been also described by Gamvroula et al. (2013). It is commonly known that the ionic composition of water is the result of several factors during water-rock interaction (Hamzaoui-Azaza et al. 2011). The water samples undersaturated with dolomite indicate that dolomite may also dissolve in this system, adding $\mathrm{Ca}^{2+}, \mathrm{Mg}^{2+}$, and $\mathrm{HCO}_{3}{ }^{-}$to the solution. Furthermore, the undersaturation by calcite indicates a chemically aggressive water able to dissolve limestone. As the water moves along the river, $\mathrm{CO}_{2}$ is lost in such quantities that the SI for calcite shifts from an undersaturated to a saturated state (point 16) where water
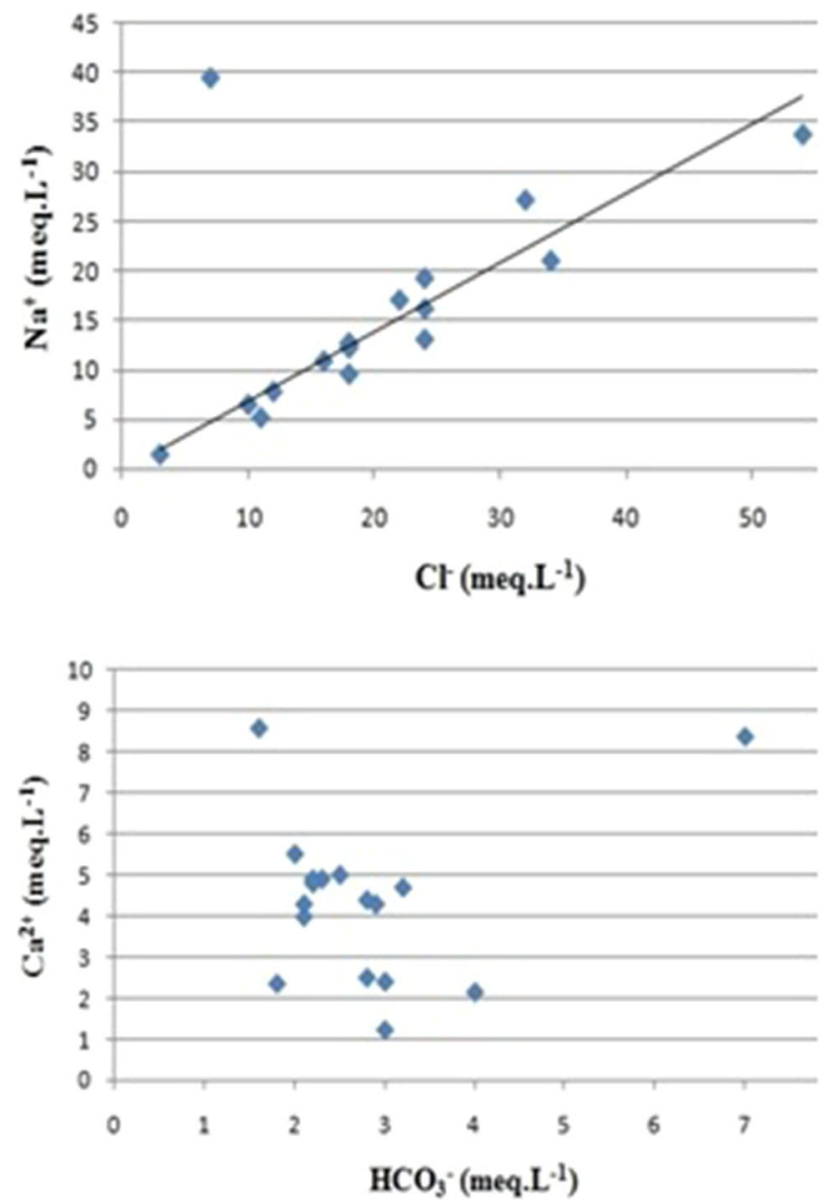

Fig. 6 Relative ionic plots of the river waters cannot dissolve limestone anymore and the calcite can precipitate to form secondary calcite (Hui et al. 2011; Sappa et al. 2012; Wanda et al. 2013).

Binary diagrams were used to better identify the origin of the salts dissolved in the river water (Fig. 6). The plot of $\mathrm{Na}^{+}$versus $\mathrm{Cl}^{-}$showed a good correlation between sodium and chloride concentrations for most of the points. This confirms that the halite dissolution is behind water salinity. Thus, this dissolution phenomenon agreed with the negative SI indicating undersaturation of the waters by halite. The plots representing $\mathrm{Ca}^{2+}$ versus $\mathrm{SO}_{4}{ }^{2-}$ concentrations yielded a good correlation between most of the points. The line representing gypsum dissolution $\left(\mathrm{CaSO}_{4} \cdot 2 \mathrm{H}_{2} \mathrm{O}\right)$ indicated that gypsum dissolution is the second source of minerals in these waters after halite. In all the samples, calcium and magnesium concentrations were not correlated to bicarbonate concentrations. This indicates that these ions do not originate from calcite $\left(\mathrm{CaCO}_{3}\right)$ and dolomite $\left(\mathrm{CaMgCO}_{3}\right)$ dissolution. The dissolution of halite and gypsum are the dominant processes controlling water salinity.
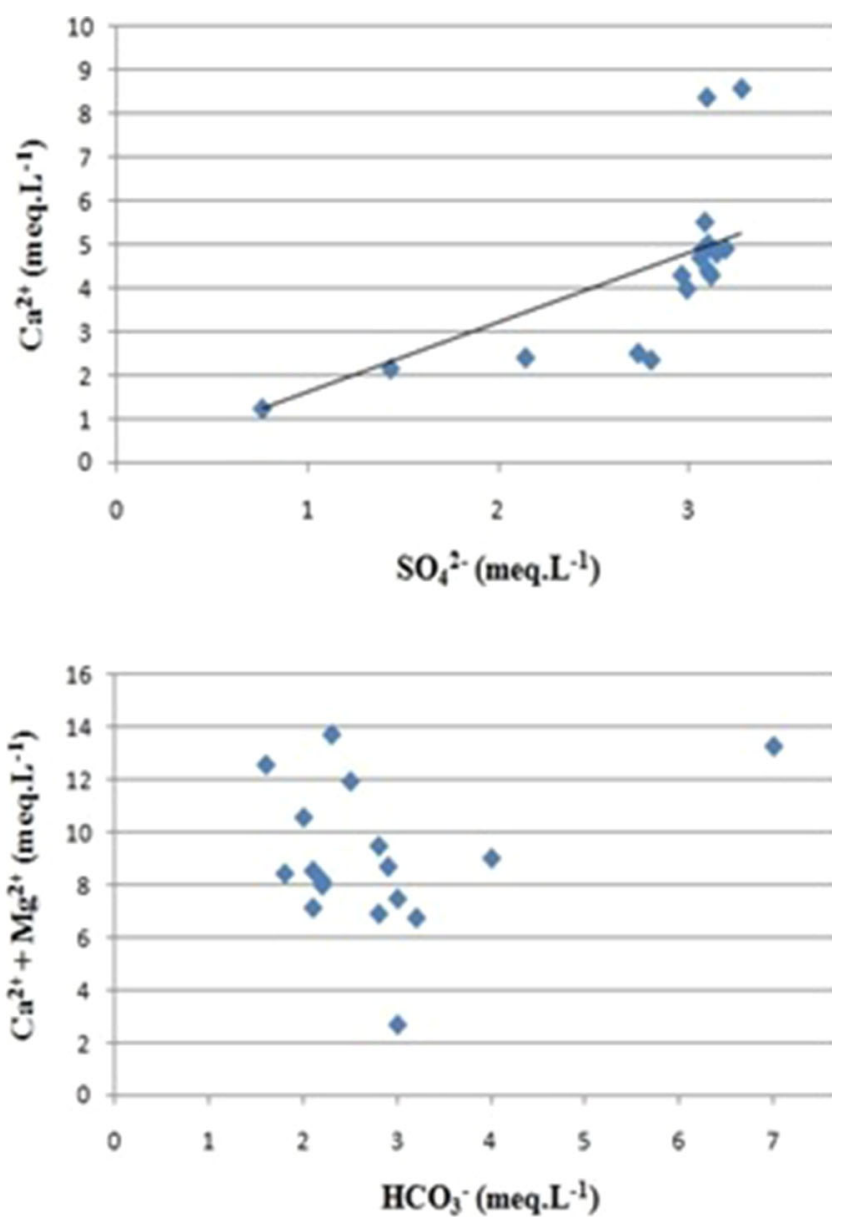
Table 2 Categorization of irrigation water in terms of infiltration capacity according to electrical conductivity (EC) and sodium adsorption ration (SAR)

\begin{tabular}{|c|c|c|c|c|}
\hline River water sampling point & $\mathrm{EC}\left(\mu \mathrm{S} \mathrm{cm}{ }^{-1}\right)$ & SAR & EC and SAR range ${ }^{a}$ & Category of hazard \\
\hline 1 & 2,810 & 4.64 & $\mathrm{SAR}=3-6$ and $\mathrm{EC}>1,200$ & I \\
\hline 2 & 3,940 & 5.59 & $\mathrm{SAR}=3-6$ and $\mathrm{EC}>1,200$ & I \\
\hline 3 & 4,930 & 7.41 & $\mathrm{SAR}=6-12$ and $\mathrm{EC}>1,900$ & I \\
\hline 4 & 1,860 & 2.36 & $\mathrm{SAR}=0-3$ and $\mathrm{EC}>700$ & I \\
\hline 5 & 7,980 & 6.62 & $\mathrm{SAR}=6-12$ and $\mathrm{EC}>1,900$ & I \\
\hline 6 & 686 & 1.10 & $\mathrm{SAR}=0-3$ and $\mathrm{EC}=200-700$ & II \\
\hline 7 & 3,550 & 5.17 & $\mathrm{SAR}=3-6$ and $\mathrm{EC}>1,200$ & I \\
\hline 8 & 1,490 & 16.70 & $\mathrm{SAR}=12-20$ and $\mathrm{EC}=1,300-2,900$ & II \\
\hline 9 & 3,260 & 3.78 & $\mathrm{SAR}=3-6$ and $\mathrm{EC}>1,200$ & I \\
\hline 10 & 5,670 & 8.35 & $\mathrm{SAR}=6-12$ and $\mathrm{EC}>1,900$ & I \\
\hline 11 & 1,850 & 3.03 & $\mathrm{SAR}=3-6$ and $\mathrm{EC}>1,200$ & I \\
\hline 12 & 2,070 & 3.39 & $\mathrm{SAR}=3-6$ and $\mathrm{EC}>1,200$ & I \\
\hline 13 & 3,090 & 4.98 & $\mathrm{SAR}=3-6$ and $\mathrm{EC}>1,200$ & I \\
\hline 14 & 3,260 & 5.01 & $\mathrm{SAR}=3-6$ and $\mathrm{EC}>1,200$ & I \\
\hline 15 & 3,220 & 4.65 & $\mathrm{SAR}=3-6$ and $\mathrm{EC}>1,200$ & I \\
\hline 16 & 7,500 & 10.25 & $\mathrm{SAR}=6-12$ and $\mathrm{EC}>1,900$ & I \\
\hline 17 & 3,640 & 6.78 & $\mathrm{SAR}=6-12$ and $\mathrm{EC}>1,900$ & I \\
\hline
\end{tabular}

Three hazard categories ( ${ }^{\text {a }}$ Ayers and Westcot 1985): (I) no problems, (II) gradual increasing problems from the continuous use of water, (III) immediate development of severe problems

\section{Irrigation water quality}

The irrigation water quality is defined by the type and the concentrations of dissolved salts and substances. In the current study, the water quality for irrigation use has been evaluated according to the criteria indicating the hazard level and the type of likely problems (Loukas 2010).

Two parameters were adopted as indicators of the suitability of the sampled waters for agricultural uses: salinity and SAR index. All water samples along the Medjerda River showed EC values higher than $700 \mu \mathrm{S} \mathrm{cm}^{-1}$ indicating the presence of salinity risks for all samples used for irrigation except Kassab wadi (point 6: $686 \mu \mathrm{S} \mathrm{cm}{ }^{-1}$ ). This comes according to FAO regulations (Ayers and Westcot 1985) that classifies hazards in three categories: (I) no problems $\left(<700 \mu \mathrm{S} \mathrm{cm}{ }^{-1}\right)$; (II) gradual increasing problems from the continuous use of water (700-3,000 $\mu \mathrm{S} \mathrm{cm}^{-1}$ ); (III) immediate development of severe problems $\left(>3,000 \mu \mathrm{S} \mathrm{cm}{ }^{-1}\right)$.

The recorded EC values range from 1,490 to $2,810 \mu \mathrm{S} \mathrm{cm}^{-1}$ for the water samples collected in points 1 , $4,8,11$ and 12 and fall into category II while the EC values for the remaining samples (points 2, 3, 5, 7, 9, 10, 13, 14, 15,16 and 17) with EC values ranging from 3,090 to $7,980 \mu \mathrm{S} \mathrm{cm}^{-1}$ fall into category III. Thus, continuous irrigation with these samples may cause increasing-to-immediate salinity problems. In fact, salinity problem is outlined when salt concentrations in soil solution exceed crop threshold levels for salt tolerance which vary from a crop to another. Water provided for irrigation in Tunisia is becoming more and more saline. Poor water quality associated with poor soil and water management has resulted in waterlogging and salinization which has reduced soil quality and agricultural productivity (Bouksila et al. 2013). Consequently, salt accumulation in the root zone leads to yield reductions (Ezlit et al. 2010).

For a proper evaluation of the ultimate effect on water infiltration rate into soil, both salinity and SAR of water should be considered. SAR is an important parameter for determining the suitability of water for irrigation because it is a measure of alkali/sodium hazard to crops. SAR also indicates irrigation water tendency to cation-exchange reactions in soil. SAR reached the lowest value of 1.1 for Kassab wadi (point 6) while the highest value was 16.7 for Beja wadi (point 8). There are also three categories of hazards according to SAR values: (I) no problems, (II) gradual increasing problems from the continuous use of water, (III) immediate development of severe problems (Ayers and Westcot 1985). Table 2 showed that most of the samples were classified in category I as their SAR values ranged between 3 and 6 . They correspond to EC higher than $1,200 \mu \mathrm{S} \mathrm{cm}^{-1}$ for the following samples (points 1,2 , $7,9,11,12,13,14,15$ ). The samples of points $3,5,10,16$ and 17 also fall into category I since their SAR ranged between 6 and 12 and their corresponding $\mathrm{EC}$ were higher than $1,900 \mu \mathrm{S} \mathrm{cm}^{-1}$. Bouhertma wadi (point 4) belongs to category I as its SAR value was less than 3 and his EC 
Fig. 7 Spatial distribution of sodium concentrations $(\mathrm{Na})$ along Medjerda River and classification in three categories (I, II and III by Ayers and Westcot 1985) in relation to water sample sodium concentrations

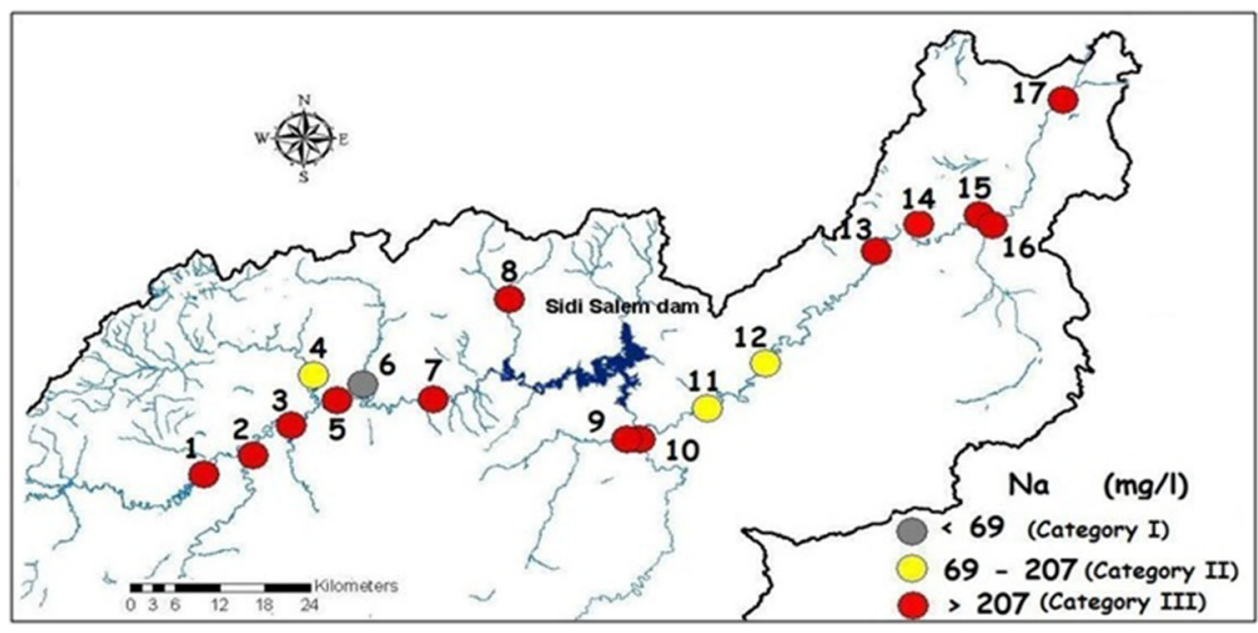

value higher than $700 \mu \mathrm{S} \mathrm{cm} \mathrm{cm}^{-1}\left(1,860 \mu \mathrm{S} \mathrm{cm}^{-1}\right)$. Thus, for all the above mentioned samples, no infiltration problem was registered. For Kassab wadi (point 6) although there is no risk of salinity, we note an infiltration risk as its SAR was less than 3 (1.1) and its EC less than 700 $\left(686 \mu \mathrm{S} \mathrm{cm}^{-1}\right)$ which indicate a possible gradual increasing problems due to the continuous use of this water for irrigation. The water collected from the Beja wadi (point 8) shows the same infiltration problems. Its SAR and EC levels belong to category II: its SAR value ranged between 12 and 20 (16.7) and its EC was less than $2,900 \mu \mathrm{S} \mathrm{cm} \mathrm{cm}^{-1}$ $\left(1,490 \mu \mathrm{S} \mathrm{cm}^{-1}\right)$. Excess of sodium in irrigation water can affect flow rate, permeability, infiltration and soil structure promoting soil dispersion.

Additionally, saline water may enable the increase in some elements concentrations which can be toxic to plants. Some examples of frequently occurring specific-ion toxicities include boron, sodium, and chloride (Kirda 1997; Nishanthiny et al. 2010). The analysis of sodium concentrations in the samples (Fig. 7) allow the categorization according to sodium toxicity from plant root intake (Ayers and Westcot 1985): less than $69.0 \mathrm{mg} \mathrm{L}^{-1}$ (category I), from 69.0 to $207.0 \mathrm{mg} \mathrm{L}^{-1}$ (category II), more than $207 \mathrm{mg} \mathrm{L}^{-1}$ (category III). It shows that irrigation with Kassab water (point 6: $35.2 \mathrm{mg} \mathrm{L}^{-1}$ ) should not cause sodium toxicity problems from plant root intake (category I). However, water collected from sampling points 4, 11 and 12 which register sodium concentrations of, respectively, $120.8,151.0$ and $181.3 \mathrm{mg} \mathrm{L}^{-1}$, showed that there is an amplification of the toxicity problem in relation to the continuous use of water (category II). The remaining sampling points, which registered a sodium level ranging between 221.6 and $906.5 \mathrm{mg} \mathrm{L}^{-1}$, may cause immediate development of severe problems of sodium toxicity from plant root intake (category III). Concerning sodium toxicity from leaf intake, all samples belong to category III as their concentrations exceed $69.0 \mathrm{mg} \mathrm{L}^{-1}$ except Kassab sample (point 6).

For the classification according to chloride toxicity from root intake (Fig. 8), Kassab wadi (point 6: $106.5 \mathrm{mg} \mathrm{L}^{-1}$ ) belongs to category I (less than $142.0 \mathrm{mg} \mathrm{L}^{-1}$ ), Beja wadi (point 8) (248.5 $\mathrm{mg} \mathrm{L}^{-1}$ ) to category II and the remaining
Fig. 8 Spatial distribution of chloride level $(\mathrm{Cl})$ along Medjerda River and classification in three categories (I, II and III) (Ayers and Westcot 1985)

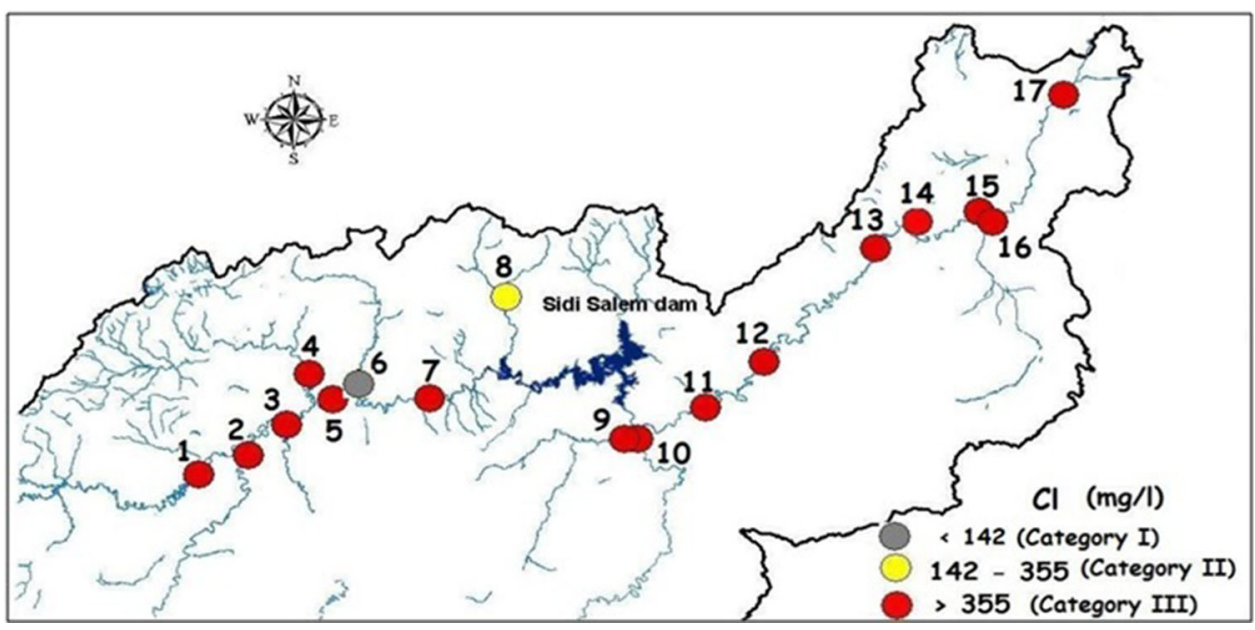


samples to category III as their chloride concentrations range from 355.0 to $1,917.0 \mathrm{mg} \mathrm{L}^{-1}$. All the samples would cause immediate chloride toxicity from root and leaf intake as their chloride concentrations are higher than $106.0 \mathrm{mg} \mathrm{L}^{-1}$.

The chemical composition of water is controlled by many factors which include the precipitation composition, the underlying geological structure, the mineralogy of the watersheds and the geochemical processes involved, as well as the residence time and the reactions that take place within the system (Hamzaoui-Azaza et al. 2011; TliliZrelli et al. 2013). In fact, modifications of the geochemical characteristics of saline waters can be due to water-rock interaction involving base exchange reactions with clay minerals, adsorption onto clay minerals and carbonate dissolution-precipitation (Thilagavathi et al. 2012; Gamvroula et al. 2013). In particular, the main factors controlling water mineralization seem to be the mineral dissolution of highly soluble salts and, of less importance, the ion exchanges. The high chloride and sodium water contents are mainly attributed to the dissolution of anhydrite, gypsum, and halite (Alexakis 2011; Tlili-Zrelli et al. 2013). Besides, high concentrations of sodium may be attributed to a base exchange reaction and leaching of sodium salts such as halite during the movement of water through sediments. Silicate dissolution can be a possible source of sodium in some water samples. Thus, water salinization would be due to ionic concentrations increase as a result of the interactions between water and geological formations (Hamzaoui-Azaza et al. 2011). However, the hydrochemical facies are not only depending on the solution kinetics, rock-water interactions and geology but also by the possible anthropogenic contaminations (Alexakis 2011). In fact, the increasing trend in the concentrations of chloride and sodium is quite alarming and may be due to an increase in industrial water pollution probably from unsupervised industrial wastewater discharge. The surface water quality is also affected by the runoff processes and the land use. Assessment of Medjerda River water quality according to the FAO standard for use in irrigation indicated that the river water could be used for irrigation but only with caution because continuous use could cause gradual to immediate problems in terms of sodium and chloride toxicity from plant root and leaf intake (Numaan 2011). Previous study assessing chloride rate in Medjerda water in the Algerian side showed that water has moderate-to-severe toxicity and that most of the points are not suitable for irrigation (Guasmi et al. 2013).

In order to assess these waters according to the US salinity diagram, EC taken as salinity hazard is plotted against SAR taken as alkalinity hazard (Fig. 9). Low sodium hazard associated with medium-to-high salinity was registered for water samples collected in points 4, 6, 11 and 12. These points belonged to $\mathrm{C} 2-\mathrm{S} 1$ and $\mathrm{C} 3-\mathrm{S} 1$ $\left(\mathrm{EC}=250-750 \mu \mathrm{S} \mathrm{cm}{ }^{-1} ; \mathrm{EC}=750-2,500 \mu \mathrm{S} \mathrm{cm}^{-1}\right.$ and SAR $<10$ ). These relatively good waters (Richards 1954), can be used for irrigation if a small risk of harmful levels of exchangeable $\mathrm{Na}^{+}$is taken into account. These waters can be used to irrigate salt-tolerant and semi-tolerant crops such as wheat, tomato, potato and onion as well as pear, apple, orange and lemon trees under favorable drainage
Fig. 9 Classification of river water in terms of degree of suitability for irrigation: electrical conductivity (Cond) versus sodium adsorption ratio SAR (after US Salinity Laboratory Staff; Richards 1954)

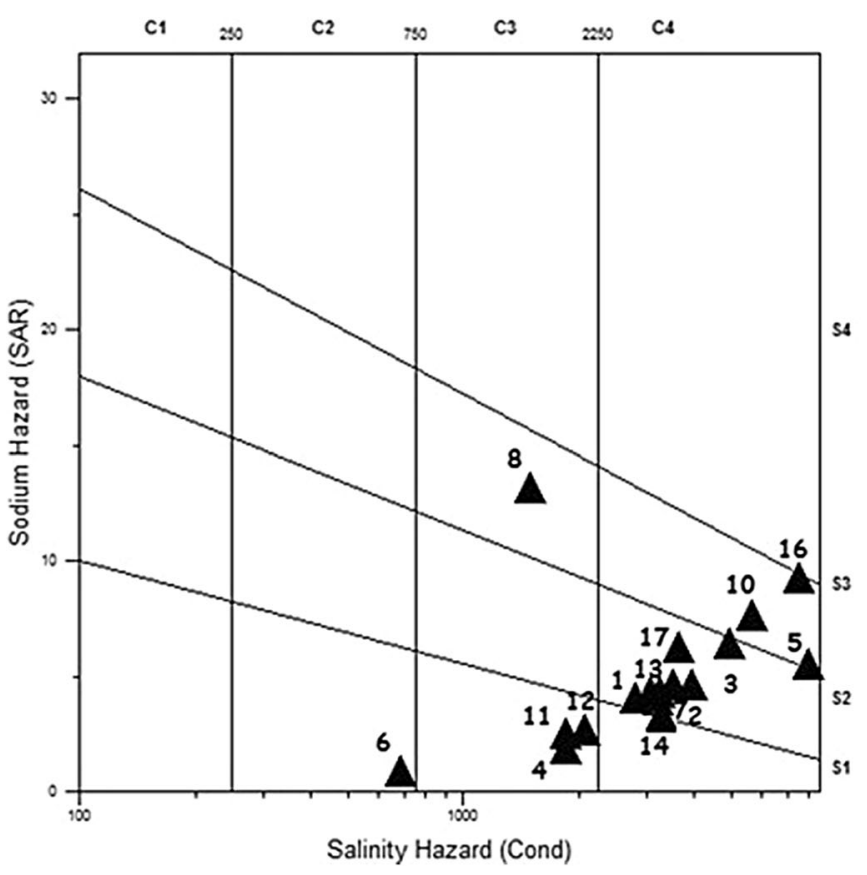

Sodium (Alkali) hazard:

S1: Low

S2: Medium

53: High

S4: Very high

Salinity hazard:

C1: Low

C2: Medium

C3: High

C4: Very high 
conditions (Sharma and Chawla 1977). Water samples collected in points 5, 8, 10 and 16 showed high alkalinity hazard and high-to-very high salinity $\mathrm{C} 3-\mathrm{S} 3$ and C4-S3 $\left(\mathrm{EC}=750-2,500 \mu \mathrm{S} \mathrm{cm}^{-1} ; \quad \mathrm{EC}>2,500 \mu \mathrm{S} \mathrm{cm}^{-1}\right.$ and SAR $>18)$ while all the remaining samples showed medium sodium hazard associated with very high salinity S2-C4 $\left(\mathrm{EC}>2,500 \mu \mathrm{S} \mathrm{cm}^{-1}\right.$ and $\left.10<\mathrm{SAR}<18\right)$. These poor-quality waters are generally undesirable for irrigation and should not be used on clayey soils of low permeability. However, they can be used to irrigate plants of high salt tolerance such as barely, sugarbeet, tobacco, mustard, cotton, sugarcane, when grown on previously salty soils to protect against further decline of fertile lands (Rao 2006).

On the basis of Wilcox diagram that classifies water samples in terms of degree of suitability for irrigation (Fig. 10), the studied river water in water samples collected in points 4, 6 and 11 belonged to the excellent-to-good and good-to-permissible irrigation water categories. Wilcox (1955) described waters with $\mathrm{EC}<750 \mu \mathrm{S} \mathrm{cm}^{-1}$ as excellent-to-good water that might be used for irrigated crops if a small risk of harmful levels of exchangeable $\mathrm{Na}^{+}$is taken into account. Wilcox described the good-to-permissible irrigation water as water that might be used to irrigate salt-tolerant and semi-tolerant under favorable drainage conditions. Furthermore, water collected from the water samples collected in points 1,8 and 12 are classified as doubtful to unsuitable while all the remaining points belonged to the unsuitable class.

Soil conditions and high salinity of the irrigation water make the lower Medjerda Valley of Tunisia difficult to cultivate. The Medjerda River water can be used most of the year for irrigation of medium-to-high salt-tolerant crops

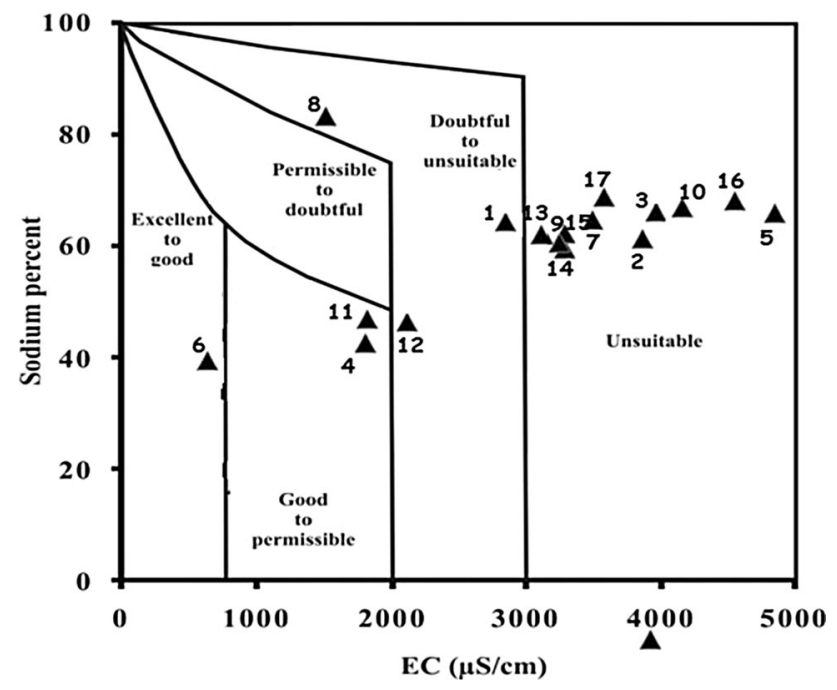

Fig. 10 Classification of river water in terms of degree of suitability for irrigation using Wilcox diagram: a plot of electrical conductivity $\mathrm{EC}$ versus $\% \mathrm{Na}^{+}$(after Wilcox 1955) such as sorghum, barley, alfalfa, rye grass, and artichokes (Ayers and Westcot 1985).

Inferior water quality may cause water-borne diseases and crop damage. It can reduce agriculture production. In order to ensure sustainable development, techniques of soil conditions improvement should be adopted. The use of fertilizers to higher crop yields should be controlled in order to reduce the percolation of excessive sodium, chloride, sulphate and nitrate into river water (Tlili-Zrelli et al. 2013). The use of drip irrigation is recommended for more effective irrigation without excessive evaporation and also for preventing weathering and leaching. Based on water quality and availability crop selection should be optimized (Rao 2006).

The nitrate concentrations in the river water ranged from 5.3 to $21.7 \mathrm{mg} \mathrm{L}^{-1}$ and were considered as acceptable since they were lower than the threshold value (22 $\mathrm{mg} \mathrm{L}^{-1}$ ) indicated by Tunisian Guidelines (INNORPI 1983). There is an increase in the nitrate concentrations when moving downstream especially in water samples collected in points 14,15 and 16 where the highest nitrate values are identified (respectively, 19.2, 19.2 and $21.7 \mathrm{mg} \mathrm{L}^{-1}$ ). These high nitrate concentrations in surface waters are explained by the intensive agricultural activities that use excessive nitrogen fertilizers to raise crop yields.

\section{Conclusion}

It is crucial to investigate the status of Medjerda water pollution to ensure its suitability for agricultural use. Sampling points were undersaturated with carbonates and evaporates except water sample collected in point 16 which was slightly supersaturated with carbonate minerals (calcite, dolomite and aragonite). The quality assessment of Medjerda River for irrigation purpose showed that water samples collected in three points out of 17 are classified as excellent-to-good and good-to-permissible irrigation water categories useful for the irrigation of salt-tolerant and midtolerant crops under favorable drainage conditions while the remaining points were classified as doubtful-to-unsuitable, making the river water use limited to plants with high salt tolerance.

The water that is suitable for irrigation is located in two of the affluent of Medjerda River. Fed by adjacent watersheds, these affluents empty into Medjerda mainstream. The only suitable point for irrigation from Medjerda mainstream is located in the mid-valley. Mid-tolerant crops should be encouraged in such areas. For the remaining locations, only plants tolerant to salt could be grown. This survey would assist managers to prioritize and make rational decisions for improving water quality used for irrigation. Some solutions can be recommended in accordance 
with the results of this study. Water salinity may be lessened by mixing salty waters with low salt concentration waters taken from other dams characterized by low water salinity. The mixing process is already adopted by the national water suppliers when they use Medjerda River water for drinking purposes: they mix treated waters from Medjerda River to treated waters from Beni Mtir dam. Additionally, the managers should use the optimal amount of irrigation water in order to satisfy leaching requirements, considering that these waters are salty and preventing the induced buildup of salts in the soil. This approach considers the electrical conductivity of the river water, the choice of the field crops as well as meteorological local conditions. Finally, the crop choice should be adapted to the water quality used for irrigation, by using salt-tolerant crop such as barley when irrigating with these salty waters.

Open Access This article is distributed under the terms of the Creative Commons Attribution License which permits any use, distribution, and reproduction in any medium, provided the original author(s) and the source are credited.

\section{References}

Alexakis D (2011) Assessment of water quality in the MessolonghiEtoliko and Neochorio region (West Greece) using hydrochemical and statistical analysis methods. Environ Monit Assess 182:397-413

Ayers RS, Westcot DW (1985) Water quality for agriculture. FAO Irrigation and Drainage Paper No. (29), Rev. (1), U.N. Food and Agriculture Organization, Rome

Bouksila F, Bahri A, Berndtsson R, Persson R, Rozema J, Van der Zee S (2013) Assessment of soil salinization risks under irrigation with brackish water in semiarid Tunisia. Environ Exp Bot 92:176-185

Bouraoui F, Benabdallah S, Jrad A, Bidoglio G (2005) Application of the SWAT model on the Medjerda river basin (Tunisia). Phys Chem Earth 30:497-507

Chabchoub MA (2011) Evaluation des systems de production méditerranéens dans un context de changement climatique. Cas de la basse vallée de la Medjerda en Tunisie, Institut Agronomique Méditerranéen de Montpellier. Master of Science CIHEAM-IAMM 113:31-36

Chapman D (1996) Water Quality Assessments-a guide to use of biota, sediments and water in environmental monitoring. Second Edition Published by E\&FN Spon, an imprint of Chapman \& Hall, UNESCO/WHO/UNEP, London SE1 8HN, UK, p 651

CIHEAM (1972) La mise en valeur de la basse-vallée de la Medjerda. L'aménagement des eaux Paris Options Méditerr 16:49-59

El Ayni F, Cherif S, Jrad A, Trabelsi-Ayadi M (2012) A new approach for the assessment of groundwater quality and its suitability for irrigation: a case study of the Korba Coastal Aquifer (Tunisia, Africa). Water Environ Res 84:673-681

Ezlit YD, Smith RJ, Raine SR (2010) Review of salinity and sodicity irrigation. CRC for Irrigation Futures Irrigation Matters Series No. 01/10, IF technologies Pty Ltd

Fan X, Cui B, Zhao H, Zhang Z, Zhang H (2010) Assessment of river water quality in Pearl River Delta using multivariate statistical techniques. Procedia Environ Sci 2:1220-1234
Faust D, Zielhofer C, Escudero RB, del Olmo FD (2004) Highresolution fluvial record of late Holocene geomorphic change in northern Tunisia: climatic or human impact? Quat Sci Rev 23:1757-1775

Gamvroula D, Alexakis D, Stamatis G (2013) Diagnosis of groundwater quality and assessment of contamination sources in the Megara basin (Attica, Greece). Arab J Geosci 6(7):2367-2381

Guasmi I, Hadji F, Jabri L (2013) Water quality of Medjerda wadi used for irrigation purpose (Eastern Algeria). Dev Soil Sal Assess Reclam 2013:701-716

Hamzaoui-Azaza F, Ketata M, Bouhlila R (2011) Hydrogeochemical characteristics and assessment of drinking water quality in Zeuss-Koutine aquifer Southeastern Tunisia. Environ Monit Assess 174(1-4):283-298

Howell TA (2003) Irrigation Efficiency. Encyclopedia of water science. Marcel Dekker, Inc., New York

Hui Q, Peiyue L, Jia D, Chao Y, Xuedi Z (2011) Formation of the river water chemistry in the middle section of Dousitu River. China EJ Chem 8:727-738

Igbinosa EO, Okoh AI (2009) Impact of discharge wastewater effluents on the physico-chemical qualities of a receiving watershed in a typical rural community. Int Environ Sci Tech $6: 175-182$

INNORPI Institut National de la Normalisation et de la Proptiété Industrielle (1983) Tunisian standards 09.13. Surface water quality. Tunis, Tunisia

Kannel PR, Lee S, Lee YS, Kanel SR, Khan SP (2007) Application of water quality indexes and dissolved oxygen as indicators for river water classification and urban impact assessment. Environ Monit Assess 132:93-110

Kanu I, Achi OK (2011) Industrial effluents and their impact on water quality of receiving rivers in Nigeria. J Appl Tech Environ Sanit $1: 75-86$

Kirda C (1997) Assessment of irrigation water quality. Options Médit A 31:368-377

Longe EO, Ogundipe AO (2010) Assessment of wastewater discharge impact from a sewage treatment plant on lagoon water, Lagos, Nigeria. Res J Appl Sci Eng Tech 2:274-282

Loukas A (2010) Surface water quantity and quality assessment in Pinios River, Thessaly, Greece. Desalination 250:266-273

Nhapi I, Tirivarombo S (2004) Sewage discharges and nutrient levels in Marimba River, Zimbabwe. Water SA 30:107-113

Nishanthiny SC, Thushyanthy M, Barathithasan T, Saravanan S (2010) Irrigation water quality based on hydro chemical analysis, Jaffna, Sri Lanka. Am Eurasian J Agric Environ Sci 7:100-102

Numaan MM (2011) Quality assessment of Tigris River by using water quality index for irrigation purpose. Eur J Sci Res 57:15-28

Parkhust DL, Appelo CAJ (1999) User Guide to PHREF QC (Version 2) - a computer programme for speciation. Batch reaction on dimensional transfer and inverse geochemical calculations, US Department of the Interior, US Geological Survey and Water Resources Investigation Report, pp 99-4259

Rao NS (2006) Seasonal variation of groundwater quality in a part of Guntur District, Andhra Pradesh, India. Environ Geol 49:413-429

Richards LA (1954) Diagnosis and improving of saline and alkali soils. United States Department of Agriculture, Hand book 60, Washington

Rogers DH, Lamm FR, Alam M, Trooien TP, Clark GA, Barnes PL, Mankin K (1997) Efficiencies and water losses of irrigation systems. Irrigation management series MF-2243. Cooperative Extension Service, Kansas State University, Manhattan

Sappa G, Barbieri M, Ergul S, Ferranti F (2012) Hydrogeological conceptual model of groundwater from carbonate aquifers using environmental isotopes $(18 \mathrm{O}, 2 \mathrm{H})$ and chemical tracers: a case 
study in southern Latium Region, Central Italy. J Water Res Prot 4:695-716

Sharma HD, Chawla AS (1977) Manual on groundwater and tube wells, in N. Subba Rao, 2006. Seasonal variation of groundwater quality in a part of Guntur District, Andhra Pradesh, India. Environ Geol 49:413-429

Stumm W, Morgan JJ (1996) Aquatic chemistry. Chemical equilibria and rates in natural waters, 3rd edn. John Wiley and Sons, Inc., New York

Thilagavathi R, Chidambaram S, Prasanna MV, Thivya C, Singaraja C (2012) A study on groundwater geochemistry and water quality in layered aquifers system of Pondicherry region, southeast India. Appl Water Sci 2(4):253-269
Tlili-Zrelli B, hamzaoui-Azaza F, Gueddari M, Bouhlila R (2013) Geochemistry and quality assessment of groundwater using graphical and multivariate statistical methods. A case study: Grombalia phreatic aquifer (Northeastern Tunisia). Arab J Geosci 6:3545-3561

Wanda EMM, Gulula LC, Phiri A (2013) Hydrochemical assessment of groundwater used for irrigation in Rumphi and Karonga districts, Northern Malawi. Phys Chem Earth 66:51-59

Wilcox LV (1955) Classification and uses of irrigation waters. US Dept. Agric Circular No. 969, Washington, DC

Wua Y, Chen J (2013) Investigating the effects of point source and nonpoint source pollution on the water quality of the East River (Dongjiang) in South China. Ecol Indic 32:294-304 